JURNAL KEBIDANAN

Vol 6, No 2, April 2020 : 236-243

\title{
PENGARUH PEMBERIAN KALSIUM DENGAN PENURUNAN TEKANAN DARAH PADA IBU PREEKLAMPSIA DI PUSKESMAS GEDUNG NEGARA, PUSKESMAS NEGARA RATU, DAN PUSKESMAS BATU NANGKOP KABUPATEN LAMPUNG UTARA
}

\author{
Eva Nauli ${ }^{1}$, Devi Kurniasari², Vida Wira Utami ${ }^{3}$ \\ 1Program Studi DIV Kebidanan Fakultas Kedokteran Universitas Malahayati Bandar Lampung \\ Korespondensi Email : Evaktb0330@gmail.com \\ 2Dosen Kebidanan Universitas Malahayati \\ Email : devikurniasari82@gmail.com \\ 3Dosen Kebidanan Universitas Malahayati \\ Email : vida@malahayati.ac.id
}

\begin{abstract}
Backgroaund The results of the preliminary study, North Lampung Regency, are known to have 23 subdistricts with high data on preeclampsia pregnant women, including Bukit Kemuning (8 cases), Abung Tinggi (6 cases), Tanjung Raja (7 cases), West Abung (5 cases), Abung Tengah (4 cases), Abung Kunang (4 cases), Abung Pekurun (5 cases), Kotabumi (14 cases), North Kotabumi (5 cases), South Kotabumi (7 cases), South Abung (9 cases), Abung Semuli (8 cases), Blambangan Yagar (7 cases), East Abung (5 cases), Surakarta Abung ( 6 cases), South Sungkai (7 cases), Muara Sungkai (9 cases), Bunga Mayang (16 cases), West Sungkai (7 cases), Sungkai Jaya (6 cases), North Sungkai (17 cases), Hulu Sungkai (13 cases), Sungkai Tengah (10 cases).

Purpose: To find out is there any effect of calcium administration by decreasing blood pressure in preeclamptic women in the State Building Health Center, Negara Ratu Health Center, and Batu Nangkop Health Center North Lampung Regency.

Methods: The type of research used is interventional analytic, while the research design used is an experimental study with pre-post group design. The population of this study were 40 trimester II and III pregnant women as many as 40 people and a sample of 40 people with total sampling technique. Data collection uses the observation sheet and the statistical test used is the paired sample t-test.

Results: The statistical test results in the intervention group using a paired sample t-test at $\alpha=0.05$ obtained $p$ values of $0.000<0.05$ for systolic and diastolic blood pressure in women with preeclampsia after calcium supplementation.

Conclusion: There is an effect of calcium administration with a decrease in blood pressure in preeclamptic women ( $p$-value $0,000<0,05)$.

Suggestion: Pregnant women do urine check one week before delivery to check urine again so that labor can be determined later whether it is included in the category of preeclampsia or not.
\end{abstract}

Keywords: Calcium, Preeclampsia

\section{ABSTRAK}

Pendahuluan: Hasil studi pendahuluan, Kabupaten Lampung Utara diketahui memiliki 23 kecamatan dengan data ibu hamil preeklampsia yang cukup tinggi, diantaranya Bukit Kemuning (8 kasus), Abung Tinggi (6 kasus), Tanjung Raja (7 kasus), Abung Barat (5 kasus), Abung Tengah (4 kasus), Abung Kunang (4 kasus), Abung Pekurun (5 kasus), Kotabumi (14 kasus), Kotabumi Utara (5 kasus), Kotabumi Selatan (7 kasus), Abung Selatan (9 kasus), Abung Semuli (8 kasus), Blambangan Yagar (7 kasus), Abung Timur (5 kasus), Abung Surakarta (6 kasus), Sungkai Selatan (7 kasus), Muara Sungkai (9 kasus), Bunga Mayang (16 kasus), Sungkai Barat (7 kasus), Sungkai Jaya (6 kasus), Sungkai Utara (17 kasus), Hulu Sungkai (13 kasus), Sungkai Tengah (10 kasus).

Tujuan: Untuk mengetahui adakah pengaruh pemberian kalsium dengan penurunan tekanan darah pada ibu preeklampsia di Puskesmas Gedung Negara, Puskesmas Negara Ratu, dan Puskesmas Batu Nangkop Kabupaten Lampung Utara.

Metode: Jenis penelitian yang digunakan adalah analitik intervensional, sedangkan rancangan penelitian yang digunakan adalah eksperimental study dengan pre-post group design. Populasi dari penelitian ini 
adalah seluruh ibu hamil trimester II dan III sebanyak 40 orang dan sampel sebanyak 40 orang dengan teknik total sampling. Pengumpulan data menggunakan lembar observasi dan uji statistik yang digunakan yaitu uji paired sample t-test.

Hasil Penelitian: Hasil uji statistik pada kelompok intervensi menggunakan uji paired sample t-test pada $a=0,05$ didapatkan nilai $p$ value masing-masing $0,000<0,05$ untuk tekanan darah sistolik dan diastolik pada ibu preeklampsia setelah diberikan suplementasi kalsium.

Kesimpulan: Ada pengaruh pemberuan kalsium dengan penurunan tekanan darah pada ibu preeklampsia ( $p$-value $0,000<0,05)$.

Saran: Ibu hamil melakukan pemeriksaan urine satu minggu sebelum persalinan untuk cek urine kembali agar dapat ditentukan persalinannya nanti apakah termasuk persalinan dengan kategori preeklampsia atau tidak.

Kata Kunci : Kalsium, Preeklampsia

\section{PENDAHULUAN}

Keberhasilan upaya kesehatan ibu, di antaranya dapat dilihat dari indikator Angka Kematian Ibu (AKI). Menurut WHO, AKI adalah kematian selama kehamilan atau dalam periode 42 hari setelah berakhirnya kehamilan, akibat semua sebab yang terkait dengan atau diperberat oleh kehamilan atau penanganan, tetapi bukan disebabkan oleh kecelakaan/cedera.(Manuaba,2010) Indikator ini tidak hanya mampu menilai program kesehatan ibu, tetapi juga mampu menilai derajat kesehatan masyarakat, karena sensitifitasnya terhadap perbaikan pelayanan kesehatan, baik dari sisi aksesibilitas maupun kualitas (Kemenkes RI, 2014). Berdasarkan data dari Dinas Kesehatan Provinsi Lampung tahun 2012- 2015, dapat dilihat angka kematian ibu di Provinsi Lampung tertinggi terjadi pada tahun 2012 yaitu sebanyak 178 kasus. Kemudian pada tahun 2013 menurun menjadi 158 kasus. Pada tahun 2014 kembali menurun menjadi 130 kasus. Namun di tahun 2015 kembali meningkat menjadi 149 kasus (Dinas Kesehatan, 2016). Penyebab kasus kematian ibu di Provinsi Lampung dari yang tertinggi ke yang terendah disebabkan oleh perdarahan sebanyak 46 kasus, hipertensi 35 kasus, gangguan sistem peredaran darah 10 kasus, infeksi 7 kasus, dan gangguan metabolik 3 kasus, selain itu disebabkan oleh penyebab lain-lain sebanyak 48 kasus (Dinas Kesehatan, 2016). Jika dilihat kembali, Kabupaten Lampung Utara termasuk dalam 3 besar kasus kematian ibu tertinggi yaitu sebesar $0,16 \%$, setelah Tulang Bawang Barat $(0,17 \%)$ dan diikuti oleh Tanggamus $(0,13 \%)$. Berdasarkan hasil studi pendahuluan, Kabupaten Lampung Utara diketahui memiliki 23 kecamatan dengan data ibu hamil preeklampsia yang cukup tinggi, diantaranya Bukit Kemuning (8 kasus), Abung Tinggi (6 kasus), Tanjung Raja (7 kasus), Abung Barat (5 kasus),
Abung Tengah (4 kasus), Abung Kunang (4 kasus), Abung Pekurun (5 kasus), Kotabumi (14 kasus), Kotabumi Utara (5 kasus), Kotabumi Selatan (7 kasus), Abung Selatan (9 kasus), Abung Semuli (8 kasus), Blambangan Yagar (7 kasus), Abung Timur (5 kasus), Abung Surakarta (6 kasus), Sungkai Selatan (7 kasus), Muara Sungkai (9 kasus), Bunga Mayang (16 kasus), Sungkai Barat (7 kasus), Sungkai Jaya (6 kasus), Sungkai Utara (17 kasus), Hulu Sungkai (13 kasus), Sungkai Tengah (10 kasus). Dari penyebab kematian ibu tertinggi, hipertensi merupakan penyebab kematian ibu nomor 2 setelah perdarahan. Berdasarkan data prasurvei yang dilakukan di Puskesmas Gedung Negara, Puskesmas Negara Ratu, dan Puskesmas Batu Nangkop didapatkan hasil ada 40 ibu hamil trimester II dan III dengan diagnosis preeklampsia. Berdasarkan penjelasan-penjelasan di atas maka peneliti tertarik untuk melakukan penelitian lebih lanjut mengenai pengaruh pemberian kalsium dengan penurunan tekanan darah pada ibu preeklampsia di Puskesmas Gedung Negara, Puskesmas Negara Ratu, dan Puskesmas Batu Nangkop Kabupaten Lampung Utara.

\section{METODE PENELITIAN}

Jenis penelitian yang digunakan adalah analitik intervensional (Notoatmojo,2012) yaitu peneliti memberikan perlakuan terhadap subyek penelitian yang sudah ditentukan, dan hasil perlakuan tersebut diamati, diukur, dan dianalisis.Penelitian dilakukan pada bulan Mei 2019 di Puskesmas Gedung Negara, Puskesmas Negara Ratu, dan Puskesmas Batu Nangkop Kabupaten Lampung Utara.Rancangan penelitian eksperimental study untuk mengetahui pengaruh pemberian kalsium dengan penurunan tekanan darah pada ibu preeklampsia di Puskesmas Gedung Negara, Puskesmas Negara Ratu, dan Puskesmas Batu Nangkop Kabupaten Lampung 
Utara. Variabel bebas yang variabel terikat yaitu penurunan tekanan darah pada ibu preeklampsia. Analisis data meliputi analisis univariat (deskriptif) dan analisis bivariat (analitik). Analisis univariat menampilkan tabel-tabel distribusi frekuensi umur ibu, paritas, IMT, LILA, umur kehamilan, tekanan darah $(\mathrm{mmHg})$ dan proteinuria $(\mathrm{mg})$ sebelum dan setelah diberikan kalsium pada kelompok perlakuan dan kelompok kontrol. Analisa data yang telah dikumpulkan secara kuantitatif dianalisis secara univariat dengan distribusi frekuensi.Analisis bivariat digunakan untuk mencari pengaruh antara variabel bebas yaitu pemberian kalsium dengan variabel terikat yaitu penurunan tekanan darah pada ibu preeklampsia menggunakan uji paired sample t-test.

\section{HASIL PENELITIAN}

Analisis Univariat

Analisis univariat adalah untuk melihat gambaran distribusi frekuensi masing-masing variabel yaitu pada variabel bebas dan variabel terikat yang diteliti. Analisis univariat pada penelitian ini menggambarkan data jumlah responden tentang distribusi frekuensi umur, paritas, IMT, LILA, dan usia kehamilan. Selanjutnya analisis univariat akan dijelaskan pada sub bab berikut ini:

Tabel 1.

Distribusi Frekuensi Karakteristik Responden di Puskesmas Gedung Negara, Puskesmas Negara Ratu, dan Puskesmas Batu Nangkop 2019.

\begin{tabular}{|c|c|c|c|c|}
\hline $\begin{array}{l}\text { Karakteristik } \\
\text { Responden }\end{array}$ & Kelompok Intervensi & Persentase (\%) & Kelompok Kontrol & Persentase (\%) \\
\hline \multicolumn{5}{|l|}{ Umur (Tahun) } \\
\hline $17-25$ & 4 & 20 & 10 & 50 \\
\hline $26-35$ & 12 & 60 & 9 & 45 \\
\hline $36-45$ & 4 & 20 & 1 & 5 \\
\hline \multicolumn{5}{|l|}{ Paritas } \\
\hline 1 & 4 & 20 & 10 & 50 \\
\hline $2-4$ & 16 & 80 & 9 & 45 \\
\hline$>4$ & 0 & 0 & 1 & 5 \\
\hline \multicolumn{5}{|l|}{ IMT } \\
\hline$<18,5$ & 0 & 0 & 2 & 10 \\
\hline $18,5-24,9$ & 15 & 75 & 14 & 70 \\
\hline $25-29,9$ & 5 & 25 & 2 & 10 \\
\hline $30-34,9$ & 0 & 0 & 2 & 10 \\
\hline \multicolumn{5}{|l|}{ LILA (cm) } \\
\hline$<23,5$ & 0 & 0 & 2 & 10 \\
\hline$\geq 23,5$ & 20 & 100 & 18 & 90 \\
\hline
\end{tabular}

Sumber: Data Primer 2019.

Hasil analisis tabel 1 didapatkan hasil bahwa berdasarkan karakteristik umur ibu pada kelompok intervensi, kelompok umur terbanyak yaitu 26 - 35 tahun dengan persentase sebesar $60 \%$. Sementara kelompok umur yang paling sedikit yaitu 17 - 25 tahun dan 36 - 45 tahun dengan persentase masing-masing sebesar $20 \%$. Pada kelompok kontrol, kelompok umur terbanyak yaitu 17 - 25 tahun dengan persentase sebesar $50 \%$. Sementara kelompok umur yang paling sedikit yaitu 36 - 45 tahun dengan persentase sebesar 5\%. Karakteristik paritas ibu pada kelompok intervensi, paritas ibu terbanyak yaitu 2 4 anak dengan persentase sebesar $80 \%$.
Sementara paritas ibu yang paling sedikit yaitu 1 anak dengan persentase sebesar 20\%. Pada kelompok kontrol, paritas ibu terbanyak yaitu 1 anak dengan persentase sebesar $50 \%$. Sementara paritas ibu yang paling sedikit yaitu $>4$ anak dengan persentase sebesar $5 \%$. Karakteristik IMT ibu pada kelompok intervensi, terdapat 15 responden atau $75 \%$ dengan berat badan normal dan terdapat 5 orang atau $25 \%$ dengan berat badan lebih. Pada kelompok kontrol, terdapat 14 responden atau $70 \%$ dengan berat badan normal, 2 responden atau $10 \%$ dengan berat badan kurang, 2 responden atau $10 \%$ dengan berat badan lebih, dan 2 responden atau 10\% dengan obesitas kelas 
1. Karakteristik LILA ibu pada kelompok intervensi, terdapat 20 responden atau $100 \%$ dengan LILA normal atau $\geq 18,5 \mathrm{~cm}$. Sedangkan pada kelompok kontrol, terdapat 2 responden atau 10\% dengan risiko KEK atau $\leq 18,5 \mathrm{~cm}$, dan 18 responden atau $90 \%$ dengan LILA normal atau $\geq 18,5 \mathrm{~cm}$. Karakteristik usia kehamilan ibu pada kelompok intervensi, terdapat 16 responden atau $80 \%$ dengan umur kehamilan berkisar 14-27 minggu dan 4 responden atau $20 \%$ dengan umur kehamilan 28 41 minggu. Sedangkan pada kelompok kontrol, terdapat 10 responden atau $50 \%$ dengan umur kehamilanc 14-27 minggu dan 10 responden atau $50 \%$ dengan umur kehamilan 28-41 minggu.

Tabel 2.

Hasil Analisis Tekanan Darah, Edema, dan Proteinuria Kelompok Intervensi di Puskesmas Gedung Negara, Puskesmas Negara Ratu, dan Puskesmas Batu Nangkop 2019.

\begin{tabular}{ccccccccccc}
\hline $\begin{array}{c}\text { Tekanan Darah Kelompok } \\
\text { Intervensi (mmHg) }\end{array}$ & \multicolumn{2}{c}{ Ederna } & \multicolumn{3}{c}{ Proteinuria } & Min & Max & Mean & SD \\
\hline Sistolik & $(+)$ & $(-)$ & $(++)$ & $(+)$ & $(-)$ & & & & \\
\hline Pre & Minggu 1 & 20 & 0 & 20 & 0 & 0 & 140 & 160 & 146,00 & 6,806 \\
& Minggu 2 & - & - & - & - & - & 120 & 150 & 138,50 & 7,452 \\
& Minggu 3 & - & - & - & - & - & 120 & 140 & 125,50 & 7,592 \\
Post & Minggu 4 & 0 & 20 & 0 & 3 & 17 & 110 & 130 & 120,00 & 5,620 \\
\hline \multirow{2}{*}{ Pre } & Diastolik & $(+)$ & $(-)$ & $(++)$ & $(+)$ & $(-)$ & & & & \\
& Minggu 1 & 20 & 0 & 20 & 0 & 0 & 90 & 90 & 90,00 & 0,000 \\
& Minggu 2 & - & - & - & - & - & 90 & 90 & 90,00 & 0,000 \\
& Minggu 3 & - & - & - & - & - & 70 & 90 & 79,50 & 6,048 \\
Post & Minggu 4 & 0 & 20 & 0 & 3 & 17 & 70 & 80 & 77,50 & 4,443 \\
\hline
\end{tabular}

Sumber: Data Primer 2019

Hasil analisis tabel 2 didapatkan bahwa tekanan darah sistolik kelompok intervensi pada minggu pertama terendah adalah $140 \mathrm{mmHg}$ dan tertinggi adalah $160 \mathrm{mmHg}$, dengan rata-rata 146 $\mathrm{mmHg}$. Pada minggu kedua, terendah adalah 120 $\mathrm{mmHg}$ dan tertinggi adalah $150 \mathrm{mmHg}$, dengan rata-rata $138,5 \mathrm{mmHg}$. Pada minggu ketiga, terendah adalah $120 \mathrm{mmHg}$ dan tertinggi adalah $140 \mathrm{mmHg}$, dengan rata-rata $125,5 \mathrm{mmHg}$. Dan pada minggu keempat, terendah adalah $110 \mathrm{mmHg}$ dan tertinggi adalah $130 \mathrm{mmHg}$, dengan rata-rata $120 \mathrm{mmHg}$. Tekanan darah diastolik kelompok intervensi pada minggu pertama terendah adalah $90 \mathrm{mmHg}$ dan tertinggi adalah $90 \mathrm{mmHg}$, dengan rata-rata $90 \mathrm{mmHg}$. Pada minggu kedua, terendah adalah $90 \mathrm{mmHg}$ dan tertinggi adalah $90 \mathrm{mmHg}$, dengan rata-rata $90 \mathrm{mmHg}$. Pada minggu ketiga, terendah adalah $70 \mathrm{mmHg}$ dan tertinggi adalah 90 $\mathrm{mmHg}$, dengan rata-rata $79,5 \mathrm{mmHg}$. Dan pada minggu keempat, terendah adalah $70 \mathrm{mmHg}$ dan tertinggi adalah $90 \mathrm{mmHg}$, dengan rata-rata 70,5 $\mathrm{mmHg}$. Edema kelompok intervensi pada minggu pertama dari total 20 responden, seluruhnya menunjukkan positif $(+)$ edema. Dan pada minggu keempat, dari total 20 responden seluruhnya menunjukkan hasil negatif (-) edema. Proteinuria kelompok intervensi pada minggu pertama dari total 20 responden, seluruhnya menunjukkan positif dua $(++)$ proteinuria. Dan pada minggu keempat, dari total 20 responden, terdapat 3 responden dengan positif satu $(+)$ proteinuria dan 17 responden dengan negatif (-) proteinuria.

Tabel 3.

Hasil Analisis Tekanan Darah, Edema, dan Proteinuria Kelompok Kontrol di Puskesmas Gedung Negara, Puskesmas Negara Ratu, dan Puskesmas Batu Nangkop 2019

\begin{tabular}{ccccccccccc}
\hline \multicolumn{2}{c}{$\begin{array}{c}\text { Tekanan Darah Kelompok } \\
\text { Kontrol (mmHg) }\end{array}$} & \multicolumn{2}{c}{ Ederna } & \multicolumn{2}{c}{ Proteinuria } & Min & Max & Mean & SD \\
\hline \multirow{2}{*}{ Pre } & Sistolik & $(+)$ & $(-)$ & $(++)$ & $(+)$ & $(-)$ & & & & \\
& Minggu 1 & 20 & 0 & 20 & 0 & 0 & 140 & 160 & 150,50 & 8,256 \\
& Minggu 2 & - & - & - & - & - & 140 & 160 & 150,50 & 7,592 \\
& Minggu 3 & - & - & - & - & - & 140 & 160 & 148,00 & 7,678 \\
Post & Minggu 4 & 0 & 20 & 0 & 0 & 0 & 130 & 160 & 148,00 & 7,678 \\
\hline
\end{tabular}




\begin{tabular}{llccccccccc}
\hline & Diastolik & $(+)$ & $(-)$ & $(++)$ & $(+)$ & $(-)$ & & & & \\
\hline Pre & Minggu 1 & 20 & 0 & 20 & 0 & 0 & 90 & 100 & 91,00 & 3,078 \\
& Minggu 2 & - & - & - & - & - & 90 & 90 & 90,00 & 0,000 \\
& Minggu 3 & - & - & - & - & - & 90 & 95 & 90,95 & 1,118 \\
Post & Minggu 4 & 0 & 20 & 0 & 0 & 0 & 90 & 90 & 90,00 & 0,000 \\
\hline
\end{tabular}

Sumber: Data Primer 2019

Hasil analisis tabel 3. didapatkan bahwa tekanan darah sistolik kelompok kontrol pada minggu pertama terendah adalah $140 \mathrm{mmHg}$ dan tertinggi adalah $160 \mathrm{mmHg}$, dengan rata-rata 150,5 $\mathrm{mmHg}$. Pada minggu kedua, terendah adalah 140 $\mathrm{mmHg}$ dan tertinggi adalah $160 \mathrm{mmHg}$, dengan rata-rata $150,5 \mathrm{mmHg}$. Pada minggu ketiga, terendah adalah $140 \mathrm{mmHg}$ dan tertinggi adalah $160 \mathrm{mmHg}$, dengan rata-rata $148 \mathrm{mmHg}$. Dan pada minggu keempat, terendah adalah $130 \mathrm{mmHg}$ dan tertinggi adalah $160 \mathrm{mmHg}$, dengan rata-rata 148 $\mathrm{mmHg}$. Tekanan darah diastolik kelompok kontrol pada minggu pertama terendah adalah $90 \mathrm{mmHg}$ dan tertinggi adalah $100 \mathrm{mmHg}$, dengan rata-rata $91 \mathrm{mmHg}$. Pada minggu kedua, terendah adalah 90 $\mathrm{mmHg}$ dan tertinggi adalah $90 \mathrm{mmHg}$, dengan ratarata $90 \mathrm{mmHg}$. Pada minggu ketiga, terendah adalah $90 \mathrm{mmHg}$ dan tertinggi adalah $95 \mathrm{mmHg}$, dengan rata-rata $90,95 \mathrm{mmHg}$. Dan pada minggu keempat, terendah adalah $90 \mathrm{mmHg}$ dan tertinggi adalah $90 \mathrm{mmHg}$, dengan rata-rata $90 \mathrm{mmHg}$. Edema kelompok kontrol pada minggu pertama dari total 20 responden, seluruhnya menunjukkan positif (+) edema. Dan pada minggu keempat, dari total 20 responden seluruhnya masih menunjukkan hasil positif $(+)$ edema. Proteinuria kelompok kontrol pada minggu pertama dari total 20 responden, seluruhnya menunjukkan positif dua $(++)$ proteinuria. Dan pada minggu keempat, dari total 20 responden, seluruhnya masih menunjukkan positif dua $(++)$ proteinuria.

\section{Analisis Bivariat}

Analisis Bivariat digunakan untuk mengetahui korelasi antara variabel independen dan variabel dependen. Analisis bivariat dilakukan menggunakan uji paired sample t-test. Probabilitas hasil hitung (skor $p<0,05)$ dinyatakan bermakna secara statistik

Kelompok intervensi

Berdasarkan tabel 4, dari 20 responden yang diamati pada kelompok intervensi terlihat bahwa rata-rata (mean) tekanan darah sistolik dari ibu sebelum diberikan suplementasi kalsium adalah $146 \mathrm{mmHg}$ dan rata-rata tekanan darah sistolik ibu setelah diberikan suplementasi kalsium adalah 120 $\mathrm{mmHg}$. Secara statistik ada perbedaan yang bermakna antara rata-rata tekanan darah sistolik ibu sebelum dan setelah diberikan suplementasi kalsium, ditunjukkan dengan nilai $p$-value sebesar 0,000 . Sedangkan rata-rata (mean) tekanan darah diastolik dari ibu sebelum diberikan suplementasi kalsium adalah $90 \mathrm{mmHg}$ dan rata-rata tekanan darah diastolik ibu setelah diberikan suplementasi kalsium adalah $77,5 \mathrm{mmHg}$. Secara statistik ada perbedaan yang bermakna antara rata-rata tekanan darah diastolik ibu sebelum dan setelah diberikan suplementasi kalsium, ditunjukkan dengan nilai $p$ value sebesar 0,000 .

Tabel 4.

Distribusi Nilai Rata-Rata Tekanan Darah lbu Pada Kelompok Intervensi Antara Sebelum dan Setelah Diberikan Suplementasi Kalsium di Puskesmas Gedung Negara, Puskesmas Negara Ratu, dan Puskesmas Batu Nangkop 2019

\begin{tabular}{|c|c|c|c|c|}
\hline Variabel & $\mathrm{n}$ & Mean & SD & $\begin{array}{c}\mathrm{p}- \\
\text { value }\end{array}$ \\
\hline \multicolumn{5}{|l|}{ Tekanan Darah } \\
\hline Pre & 20 & 146 & 6,806 & \multirow{2}{*}{0,000} \\
\hline Post & 20 & 120 & 5,620 & \\
\hline \multicolumn{5}{|l|}{ Tekanan Darah } \\
\hline Diastolik & & & & \multirow[b]{2}{*}{0,000} \\
\hline $\begin{array}{l}\text { Pre } \\
\text { Post }\end{array}$ & $\begin{array}{l}20 \\
20\end{array}$ & $\begin{array}{c}90 \\
77,5\end{array}$ & $\begin{array}{l}0,000 \\
4,443\end{array}$ & \\
\hline \multicolumn{5}{|c|}{ Sumber : Data Primer 2019} \\
\hline \multicolumn{5}{|c|}{ Kelompok control } \\
\hline \multicolumn{5}{|c|}{$\begin{array}{c}\text { Tabel } 5 . \\
\text { Distribusi Nilai Rata-Rata Tekanan Darah Ibu } \\
\text { Pada Kelompok Kontrol di Puskesmas Gedung } \\
\text { Negara, Puskesmas Negara Ratu, dan } \\
\text { Puskesmas Batu Nangkop } 2019\end{array}$} \\
\hline Variabel & $\mathrm{n}$ & Mean & SD & $\begin{array}{c}p- \\
\text { value }\end{array}$ \\
\hline $\begin{array}{l}\text { Tekanan Darah } \\
\text { Sistolik }\end{array}$ & & & & \\
\hline $\begin{array}{c}\text { Pre } \\
\text { Post } \\
\text { Tekanan Darah } \\
\text { Diastolik }\end{array}$ & $\begin{array}{l}20 \\
20\end{array}$ & $\begin{array}{c}150,5 \\
148\end{array}$ & $\begin{array}{l}8,256 \\
7,678\end{array}$ & 0,135 \\
\hline
\end{tabular}




$\begin{array}{lllll}\text { Pre } & 20 & 91 & 3,078 & 0,163 \\ \text { Post } & 20 & 90 & 0,000\end{array}$

Sumber : Data Primer 2019

Berdasarkan tabel 5 , dari 20 responden yang diamati pada kelompok kontrol terlihat bahwa rata-rata (mean) tekanan darah sistolik dari ibu sebelum penelitian adalah $150,5 \mathrm{mmHg}$ dan ratarata tekanan darah sistolik ibu setelah penelitian adalah $148 \mathrm{mmHg}$. Secara statistik tidak ada perbedaan yang bermakna antara rata-rata tekanan darah sistolik ibu sebelum dan setelah penelitian, ditunjukkan dengan nilai p-value sebesar 0,135. Sedangkan rata-rata (mean) tekanan darah diastolik dari ibu sebelum penelitian adalah 91 $\mathrm{mmHg}$ dan rata-rata tekanan darah diastolik ibu setelah penelitian adalah $90 \mathrm{mmHg}$. Secara statistik tidak ada perbedaan yang bermakna antara ratarata tekanan darah diastolik ibu sebelum dan setelah penelitian, ditunjukkan dengan nilai $p$-value sebesar 0,163.

Berdasarkan tabel 6 didapatkan nilai RR sebesar 1,154 dengan lower - upper sebesar 0,946 $-1,407$.

Tabel 6.

Nilai RR Suplementasi Kalsium

\begin{tabular}{ccc}
\hline Relative Risk (RR) & Lower & Upper \\
\hline 1,154 & 0,946 & 1,407 \\
\hline
\end{tabular}

Sumber : Data Primer 2019

\section{PEMBAHASAN}

\section{Analisis Univariat}

Penelitian tentang Pengaruh Pemberian Kalsium Dengan Penurunan Tekanan Darah Pada Ibu Preeklampsia di Puskesmas Gedung Negara, Puskesmas Negara Ratu, dan Puskesmas Batu Nangkop Kabupaten Lampung Utara. Penelitian ini menggunakan data hasil penelitian peneliti selama 30 hari terhitung mulai bulan Mei 2019 - Juni 2019 di Puskesmas Gedung Negara, Puskesmas Negara Ratu, dan Puskesmas Batu Nangkop Kabupaten Lampung Utara. Data responden yang diambil sebagai sampel yaitu data yang memenuhi kriteria inklusi dan eksklusi. Sampel yang didapat berdasarkan kriteria tersebut adalah sebesar 40 responden yang dibagi menjadi dua kelompok, yaitu kelompok intervensi dan kelompok kontrol dengan perbandingan 1:1. Jumlah tersebut didapat dari data ibu hamil trimester II dan III yang rutin memeriksakan kehamilannya di Puskesmas Gedung Negara, Puskesmas Negara Ratu, dan
Puskesmas Batu Nangkop Kabupaten Lampung Utara.

Berdasarkan hasil penelitian didapatkan hasil bahwa dari 40 responden, diketahui kelompok umur tertinggi yaitu 26 - 35 tahun sebanyak 21 responden dan yang terendah pada kelompok umur 36 - 45 tahun sebanyak 5 responden. Pada kategori paritas ibu, tertinggi pada kelompok $2-4$ anak sebanyak 25

responden, sedangkan paritas terendah pada kelompok $>4$ anak sebanyak 1 responden. Pada kategori IMT, responden terbanyak dengan kategori berat badan normal sebanyak 29 responden, sedangkan kategori berat badan kurang, lebih, dan obesitas tipe 1, masing-masing sebanyak 2 responden. Pada kategori LILA ibu, terdapat 38 responden dengan LILA normal atau $\geq$ $18,5 \mathrm{~cm}$ dan 2 responden dengan risiko KEK atau $\leq$ $18,5 \mathrm{~cm}$. Pada kategori umur kehamilan, terdapat 26 responden dengan umur kehamilan berkisar 1427 minggu dan 14 responden dengan umur kehamilan 28-41 minggu.

\section{Analisis Bivariat}

Berdasarkan hasil uji statistik pada kelompok intervensi menggunakan uji paired sample t-test pada $a=0,05$ didapatkan nilai $p$ value masing-masing 0,000 $<0,05$ untuk tekanan darah sistolik dan diastolik pada ibu preeklampsia setelah diberikan suplementasi kalsium, atau $\mathrm{HO}$ ditolak. Dengan demikian, terdapat pengaruh pemberian kalsium dengan penurunan tekanan darah ibu preeklampsia.

Sedangkan hasil uji statistik pada kelompok kontrol menggunakan uji paired sample ttest pada $\alpha=0,05$ didapatkan nilai $p$ value masingmasing 0,135 dan 0,163>0,05 untuk tekanan darah sistolik dan diastolik pada ibu preeklampsia atau $\mathrm{HO}$ diterima. Dengan demikian, tidak terdapat perbedaan pada pemeriksaan tekanan darah sebelum dan setelah penelitian.

Berdasarkan hasil analisis RR, didapatkan hasil bahwa orang yang yang tidak mengkonsumsi kalsium selama kehamilan berisiko 1,154 kali untuk mengalami preeklampsia dibandingkan orang yang mengkonsumsi kalsium selama kehamilan. Atau dapat artikan bahwa orang yang mengkonsumsi kalsium selama kehamilan berisiko 1/1,154 atau 0,86 kali lebih kecil untuk mengalami preeklampsia dibandingkan orang yang tidak mengkonsumsi kalsium selama kehamilan. Nilai $\mathrm{Cl} 95 \%$ diantara $0,946-1,407$ berarti risiko bersifat protektif.

Mineral kalsium selama ini diketahui dapat menurunkan tekanan darah. Mineral tersebut menghambat terjadinya konstriksi pembuluh darah 
yang menyebabkan penurunan resistensi perifer sehingga terjadi penurunan tekanan darah. Selama ini penelitian epidemiologi tentang asupan kalsium dan magnesium dalam menurunkan tekanan darah masih kontroversial (Lestari,2010).

Menurut Omotayo (2016), kalsium juga dapat mengurangi resiko pereklamsia atau suatu kondisi dimana ibu hamil mengalami tekanan darah tinggi dan protein dalam urine dan harus melahirkan bayi lebih awal. Kekurangan kalsium juga dapat memengaruhi perkembangan kardiovaskuler pada janin dan meningkatkan tekanan darah tinggi setelah bayi lahir. Kalsium merupakan mineral yang paling banyak terdapat didalam tubuh manusia. Kira-kira 99\% kalsium terdapat di dalam jaringan keras yaitu pada tulang dan gigi, $1 \%$ kalsium terdapat pada darah, dan jaringan lunak. Tanpa kalsium yang $1 \%$ ini, otot akan mengalami gangguan kontraksi, darah akan sulit membeku, transmisi saraf terganggu, dan sebagainya.

Hasil penelitian ini sesuai dengan yang dilakukan oleh Nofita (2018) yang menyatakan bahwa terdapat hubungan antara kepatuhan konsumsi kalsium pada ibu hamil dengan kejadian resiko tinggi preeklamsia pada ibu hamil dengan $p$ value 0,012 .

Penelitian dilakukan pada 40 ibu hamil trimester II dan III yang sebelumnya telah di diagnosis preeklampsia oleh dokter puskesmas dan bersedia menjadi responden. Peneliti memberikan intervensi pada 20 responden dan sisanya dijadikan sebagai pembanding sehingga hasil dapat lebih menggambarkan apakah benar terdapat pengaruh penurunan tekanan darah setelah diberikan suplementasi kalsium. Intervensi berupa suplementasi kalsium dengan dosis 2x500 mg kalsium selama 1 bulan. Responden kemudian dipantau setiap minggunya (minggu pertama keempat) untuk dilakukan pengukuran ulang tekanan darah untuk dilihat apakah ada penurunan tekanan darah pada ibu, pemeriksaan penunjang lainnya seperti pemeriksaan edema dan pemeriksaan proteinuria dilakukan pada minggu pertama dan minggu keempat.

Hasil observasi didapatkan bahwa responden yang diberikan suplementasi kalsium, pada minggu ketiga dan keempat menunjukkan penurunan tekanan darah yang signifikan dengan rata-rata $120 \mathrm{mmHg}$ untuk tekanan darah sistolik dan $77,5 \mathrm{mmHg}$ untuk tekanan darah diastolik serta diiringi dengan hilangnya edema dan penurunan proteinuria. Sedangkan pada responden yang tidak diberikan suplementasi kalsium, tidak menunjukkan penurunan tekanan darah yang signifikan, cenderung stabil dari pengukuran minggu pertama hingga minggu keempat serta edema dan proteinuria tetap positif, dengan rata-rata 148 $\mathrm{mmHg}$ untuk tekanan darah sistolik dan $90 \mathrm{mmHg}$ untuk tekanan darah diastolik. Namun beberapa responden menunjukkan penurunan tekanan darah dan setelah diobservasi ternyata responden sudah diberikan juga suplementasi kalsium di posyandu, namun hanya 10 tablet selama satu bulan. Sehingga pada saat pengukuran tekanan darah beberapa responden menunjukkan penurunan tekanan darah dari minggu sebelumnya.

\section{KESIMPULAN}

Orang yang yang tidak mengkonsumsi kalsium selama kehamilan berisiko 1,154 kali untuk mengalami preeklampsia dibandingkan orang yang mengkonsumsi kalsium selama kehamilan. Atau dapat artikan bahwa orang yang mengkonsumsi kalsium selama kehamilan berisiko 1/1,154 atau 0,86 kali lebih kecil untuk mengalami dibandingkan orang yang tidak mengkonsumsi kalsium selama kehamilan.

\section{SARAN}

Bagi Puskesmas Gedung Negara, Puskesmas Negara Ratu, dan Puskesmas Batu Nangkop Kabupaten Lampung Utara diharapkan pemberian suplementasi kalsium perlu dijadikan kegiatan rutin puskesmas untuk mendukung penurunan angka ibu hamil dengan preeklampsia Puskesmas Gedung Negara, Puskesmas Negara Ratu, dan Puskesmas Batu Nangkop di Kabupaten Lampung Utara. Karena masih banyak ditemukan ibu hamil khususnya pada trimester II dan III yang memiliki tekanan darah tinggi sehingga memperbesar risiko untuk preeklampsia jika tidak ditangani dengan baik. Bagi Tenaga Kesehatan diharapkan bagi tenaga kesehatan untuk dapat memberikan suplementasi kalsium pada trimester II dan III berjumlah 90 tablet dan setiap bulannya melakukan pemantauan agar suplementasi yang diberikan benar-benar memberikan hasil maksimal pada ibu hamil. Bagi Ibu Hamil hasil penelitian ini diharapkan agar ibu hamil melakukan pemeriksaan urine satu minggu sebelum persalinan untuk cek urine kembali agar dapat ditentukan persalinannya nanti apakah termasuk persalinan dengan kategori preeklampsia atau tidak.Bagi Peneliti Selanjutnya hasil penelitian ini diharapkan dapat menjadi bahan referensi guna melakukan penelitian yang sama, dan peneliti selanjutnya diharapkan dapat meneliti lebih lanjut variabel lain dan faktor risiko lainnya yang juga berpengaruh terhadap kejadian preeklampsia. 


\section{DAFTAR PUSTAKA}

Lampung, D. K. P. (2016). Profil Provinsi Lampung Tahun 2015. Bandar Lampung: Dinas Kesehatan Pemerintah Provinsi Lampung.

Lestari, D., \& Lelyana, R. (2010). Hubungan Asupan Kalium, Kalsium, Magnesium, dan Natrium, Indeks Massa Tubuh, serta Aktifitas Fisik dengan Kejadian Hipertensi pada Wanita Usia 30-40 Tahun (Doctoral dissertation, Program Studi IImu Gizi).

Kemenkes, R. I. (2014). Situasi Kesehatan Ibu. Infodatin. Jakarta: Kementerian Kesehatan Republik Indonesia.

Keman, K. (2014). Patomekanisme Preeklampsia Terkini: Mengungkapkan teori-teori terbaru tentang patomekanisme preeklampsia dilengkapi dengan deskripsi biomokuler. Universitas Brawijaya Press.

Mahan, L. K. (2004). Krause's food, nutrition, \& diet therapy (Vol. 11). S. Escott-Stump (Ed.). Philadelphia:Saunders.

Lalenoh, D. C. (2018). Preeklampsia Berat dan Eklampsia: Tatalaksana Anestesia Perioperatif. Deepublish.

Li, K., Kaaks, R., Linseisen, J., \& Rohrmann, S. (2012). Associations of dietary calcium intake and calcium supplementation with myocardial infarction and stroke risk and overall cardiovascular mortality in the Heidelberg cohort of the European Prospective Investigation into Cancer and Nutrition study (EPICHeidelberg). Heart, 98(12), 920-925.

Manuaba, I. B. G., Manuaba, I. B. G. F., \& Manuaba, I. B. G. (2010). IImu Kebidanan, Penyakit Kandungan dan KB untuk Pendidikan Bidan. Jakarta: EGC, 421-424.

Maryunani, A. (2009). Asuhan kegawatdaruratan dalam Kebidanan.

Notoatmodjo, S. (2012). Metodologi penelitian kesehatan (Cetakan VI). Jakarta: Penerbit PT. Rineka Cipta.

Nofita, R., \& Anjansari, F. R. (2018). Korelasi Waktu Pemberian Kalsium, dan Kepatuhan Konsumsi Kalsium dengan Kejadian Resiko Tinggi Pre Eklamsia lbu Hamil Di Wilayah Kerja Puskesmas Ciputat. Indonesian Journal of Midwifery (IJM), 1(1).

Omotayo, M. O., Dickin, K. L., O'Brien, K. O., Neufeld, L. M., De Regil, L. M., \& Stoltzfus, R. J. (2016). Calcium supplementation to prevent preeclampsia: translating guidelines into practice in low-income countries. Advances in Nutrition, 7(2), 275278. 